\title{
Peripheral nerve conduction in Miller Fisher syndrome
}

\author{
R. J . G U I L O F F
}

From the National Hospital for Nervous Diseases, Queen Square, London

SUMMARY Two cases of acute ophthalmoplegia, ataxia, and arreflexia with high CSF protein are reported (Miller Fisher syndrome). Detailed EMG and nerve conduction studies showed abnormal conduction in peripheral sensory fibres from the initial stages of the illness in both patients. Careful review up to 10 months after the onset was required to document the sensory conduction abnormality properly in one of them. The electrical findings did not differ from those that can be seen in the Guillain-Barré syndrome and provided no clues as to the mechanism of the ataxia.

The syndrome of acute ophthalmoplegia, ataxia, and arreflexia is accepted by most authors (Van Allen and MacQueen, 1964; Munsat and Barnes, 1965; Elizan et al., 1971), including Miller Fisher who first focused attention on it in 1956, as a variant of acute idiopathic polyneuritis or Guillain-Barré syndrome. The syndrome has a benign course and is rare so that it is not surprising that there have been no electrophysiological or pathological reports in the literature.

Ophthalmoplegia (Collier, 1932; Haymaker and Kernohan, 1949) and ataxia (Baruk and Poumeau de Lille, 1934; Guillain, 1936) have both long been known to occur separately as prominent signs in patients with the Guillain-Barré syndrome, and postmortem material is available in both (Russell and Moore, 1943; Haymaker and Kernohan, 1949; Richter, 1962; Bignami and Senin, 1963). But although there are many reports on electromyographic and nerve conduction studies in acute idiopathic polyneuritis (for references see McLeod et al., 1976), none deals specifically with the Miller Fisher syndrome of acute ophthalmoplegia with ataxia and arreflexia. Its inclusion in the group of acute idiopathic polyneuritis still rests largely on purely clinical grounds and on inferences drawn from pathological data in cases of Guillain-Barré syndrome (vide supra and also Marinesco, 1927; Van Bogaert 1958; Martin, 1960; Asbury et al., 1969).

Address for reprint requests: National Hospital for Nervous Diseases, Maida Vale Hospital, London W9 1TL, England.

Accepted 13 March 1977
The aim of this paper is to present detailed electromyographic and nerve conduction data in two cases of Miller Fisher syndrome, to consider whether they are consistent with the current view that it represents a form of acute idiopathic polyneuritis, and to illustrate the importance of serial electrical studies in assessing retrospectively the findings in the initial stages of the illness. In addition, the relevance of the results to the interpretation of the mechanism of the ataxia will be briefly mentioned.

\section{Methods}

Electromyography and nerve conduction studies were performed with a Medelec model MS6 electromyograph. Stimulation was carried out using a constant voltage electrical stimulator set to deliver $0.1 \mathrm{~ms}$ square wave pulses through silver button or ring electrodes covered with lint soaked in saline. The recording electrodes were concentric needle electrodes or bars covered in saline-soaked lint, mounted on Perspex with a separation of $40 \mathrm{~mm}$. For sensory action potentials (SAPs) the AA6 amplifier was set to a deflection of $10 \mu \mathrm{V} / \mathrm{cm}$ with a time constant of $5 \mathrm{~ms}$ and a $\mathrm{HF}$ cut at $5 \mathrm{kHz}$. In case 1 responses were averaged by an AV6 averager, and in case 2 several single action potentials were displayed. SAPs were recorded as described by Gilliatt and Sears (1958) for median and ulnar nerves, by Downie and Scott (1967) for radial nerve, and by Di Benedetto (1970) for sural nerve. Mixed nerve action potentials were recorded as described by Gilliatt et al. 
(1961) for lateral popliteal nerve, and Gilliatt and Thomas (1960) for ulnar nerve. Ambient temperature was $21-26^{\circ} \mathrm{C}$. Limb temperature was measured by a thermistor probe.

\section{Case reports}

CASE 1

GW (A70802), a 70 year old man, was admitted to hospital on 9 February 1976 with a five day history of progressive unsteadiness of gait and clumsiness in the upper limbs, and intermittent horizontal diplopia for 24 hours. He had also noticed a tight sensation in his fingers and toes, and his wife thought that his speech had become slightly slurred. Three weeks before admission he had suffered from sore throat, cough, and shivering which resolved after two weeks. He had had malaria in 1940 and a partial gastrectomy for duodenal ulcer in 1943. In April 1973 he had been seen at the National Hospital for a left Bell's palsy, and absent upper limb reflexes were then noted. At that time electromyography of the left orbicularis oculi muscle showed a moderately reduced interference pattern but no spontaneous activity. Latency of response of that muscle to stimulation of the facial nerve at the tragus was $3.2 \mathrm{~ms}$. The right median (F2-wrist) and ulnar (F5-wrist) sensory action potentials were 11 and $6 \mu \mathrm{V}$ amplitude respectively and had latencies to peak of $3.3 \mathrm{~ms}$ and $2.6 \mathrm{~ms}$. In June and July 1974 he had two minor left hemisphere strokes, the first with dysphasia, and he was admitted to hospital. He was found to be hypertensive (180/ $110 \mathrm{mmHg}$ ) and had minimal spasticity and weakness in the right arm. Reflexes were then present in the upper and lower limbs. Vibration sense was absent in the toes. Blood Wassermann, VDRL, and RPCFT tests were negative but TPHA and FTA for syphilis were positive. CSF examination showed a protein level of $0.78 \mathrm{~g} / 1$, one polymorph per $\mathrm{mm}^{3}$, sugar $3.2 \mathrm{mmol} / 1$ ( $\left.58 \mathrm{mg} / \mathrm{dl}\right)$, Pandy test positive, Lange curve normal, IgG was $4.8 \%$ of total protein. CSF serology was negative for syphilis. Random estimation of blood sugar, serum B12 and folate, red cell folate, chest radiograph, and ECG were normal. An EMI scan showed appearances of cerebral atrophy. He was given one injection of benzathine penicillin 2.4 mega units intramuscularly and methyldopa $250 \mathrm{mg}$ thrice daily, and discharged. During 1974 and in November 1975 he had a few episodes of paraesthesia in the fingers and toes.

On admission to hospital in 1976 he was fully alert and slightly dysarthric. The gait was very ataxic and he could just walk unaided. $\mathrm{He}$ had bilateral partial ptosis more marked on the left, normally reacting pupils, marked limitation of upward and downward gaze and of abduction and adduction of the left eye but only slight on adduction of the right eye. Abduction of the right eye was full. The eye movements did not improve with the doll's head manoeuvre nor with injection of $10 \mathrm{mg}$ of edrophonium chloride intravenously. Tone was generally reduced. He had slight weakness, proximally more than distally, in upper and lower limbs. He could not sit unaided. There was gross finger-nose ataxia, trunk ataxia, and moderate heel-shin ataxia not significantly worsened by eye closure. Deep tendon and abdominal reflexes were absent. Plantar responses were flexor. Vibration sense was absent below the clavicles and two point discrimination was slightly impaired in all digits (mistakes with $4 \mathrm{~mm}$ point separation). Other sensory modalities were normal. Blood pressure was $180 / 100 \mathrm{mmHg}$, pulse rate 60 per min.

The ophthalmoplegia became almost total a few days after admission. By 18 February he also had slight impairment of joint position sense in the fingers and toes, and mild impairment to pin prick and cotton wool distally in the feet and hands. By 23 February the ataxia had largely resolved but he developed a right lower motoneurone facial weakness. By 11 March the only remaining signs were slight impairment of upward gaze and adduction of the left eye and absent deep tendono reflexes.

\section{INVESTIGATIONS}

Lumbar puncture on 10 February 1976 showed CSF pressure of $110 \mathrm{~mm}$ of water. The protein content of the CSF was $1.2 \mathrm{~g} / 1$, Pandy slightly positive, Lange curve 1223000000 . The CSF contained two erythrocytes and two mononuclear cells per $\mathrm{mm}^{3}, 4 \mathrm{mmol} / 1$ of sugar $(80 \mathrm{mg} / \mathrm{dl})$ and the IgG was $6 \%$ of total protein. Tests for viral antibodies negative. Haematological, biochemical and virological screenings were negative. A normal audiogram was recorded on 17 February and caloric tests did not induce nystagmus; the eyes moved minimally in the direction of the slow component and he developed slight vertigo. It was remarked that the virtual absence of vertigo with the caloric test was compatible with involvement of the vestibular nerves peripherally ( $\mathrm{Dr} \mathrm{P}$. Rudge).

\section{Electromyography and nerve conduction studies} Sampling with a concentric needle electrode showed normal findings in the left abductor pollicis brevis muscle. The following muscles showed a 
slightly reduced interference pattern but no evidence of denervation: right abductor pollicis brevis (APB), right first dorsal interosseous, right biceps, right deltoid, right quadriceps, and right tibials anterior (13 and 19 February 1976). Motor and sensory conduction studies performed nine days after the onset are summarised in Table 1 . The findings for mixed nerve action potentials are summarised in Table 2 . The $\mathrm{H}$ reflex was absent in the right calf. On 31 March a follow-up study showed a right median SAP of $3 \mu \mathrm{V}$ (F2-wrist) with $4.4 \mathrm{~ms}$ latency to peak but the right sural SAP remained absent. Right median nerve motor conduction velocity was $50 \mathrm{~m} / \mathrm{s}$ with distal motor latency to APB of $3.4 \mathrm{~ms}$. Values for the right lateral popliteal nerve were $34 \mathrm{~m} / \mathrm{s}$ and $6.1 \mathrm{~ms}$.

CASE 2

VJ (A63695), a 27 year old man, was admitted to hospital on 16 January 1972 with a two day progressive history of paraesthesia and numbness of hands, feet, and tongue spreading to the rest of the body and around the mouth, unsteadiness of gait, poor control of limb movements, drooping of the right and later left eyelid, weakness of hands and legs, loss of anal sensation, and loss of penile erection. Two weeks before admission he had a sore throat. On admission his gait was very ataxic and Romberg's sign was positive. He had severe bilateral ptosis. Ocular movements were full and pupils were large and reacted sluggishly to light but briskly to convergence. There was mild bilateral facial weakness. There was minimal weakness proximally but marked ataxia in upper and lower limbs, more in the latter, total arreflexia, and flexor plantar responses. He had slight subjective impairment of pin prick and light touch sensation distally in hands and feet. Joint position

Table 1 Motor and sensory conduction studies nine days after onset of Miller Fisher syndrome (case 1)

\begin{tabular}{|c|c|c|c|c|c|c|}
\hline Nerve & Test & Electrode & Segment & Right & Left & Normal values \\
\hline Median & $\begin{array}{l}\text { DML } \\
\text { MCV } \\
\text { SAP }\end{array}$ & $\begin{array}{l}\text { Concentric needle } \\
\text { Concentric needle } \\
\text { surface }\end{array}$ & $\begin{array}{l}\text { wrist-APB } \\
\text { elbow-wrist } \\
\text { F2-wrist }\end{array}$ & $\begin{array}{l}4.3 \\
49 \\
\text { absent }\end{array}$ & $\begin{array}{l}4.3 \\
60 \\
\text { absent }\end{array}$ & $\begin{array}{l}2.8-4.8 \\
49-65 \\
9-45\end{array}$ \\
\hline Ulnar & $\begin{array}{l}\text { DML } \\
\text { MCV } \\
\text { MAP } \\
\text { MAP } \\
\text { SAP }\end{array}$ & $\begin{array}{l}\text { surface } \\
\text { surface } \\
\text { surface } \\
\text { surface } \\
\text { surface }\end{array}$ & $\begin{array}{l}\text { wrist-ADM } \\
\text { elbow-wrist } \\
\text { wrist-ADM } \\
\text { elbow-ADM } \\
\text { F5-wrist }\end{array}$ & $\begin{array}{l}3.0 \\
55 \\
8.8 \\
5.6 \\
\text { absent }\end{array}$ & $\begin{array}{l}3.9 \\
50 \\
4 \\
2.3 \\
\text { absent }\end{array}$ & $\begin{array}{l}<4.0 \\
47-65 \\
>3 \\
>3 \\
7-28\end{array}$ \\
\hline Radial & SAP & surface & wrist-F1 & absent & not done & $5-20$ \\
\hline $\begin{array}{l}\text { Lateral } \\
\text { popliteal }\end{array}$ & $\begin{array}{l}\text { DML } \\
\text { MCV } \\
\text { MAP } \\
\text { MAP }\end{array}$ & $\begin{array}{l}\text { surface } \\
\text { surface } \\
\text { surface } \\
\text { surface }\end{array}$ & $\begin{array}{l}\text { ankle-EDB } \\
\text { knee-ankle } \\
\text { ankle-EDB } \\
\text { knee-EDB }\end{array}$ & $\begin{array}{l}6 \\
40 \\
3.0 \\
2.5\end{array}$ & $\begin{array}{l}\text { not done } \\
\text { not done } \\
\text { not done } \\
\text { not done }\end{array}$ & $\begin{array}{l}<7.0 \\
36-64 \\
>3.0 \\
>3.0\end{array}$ \\
\hline Sural & SAP & surface & calf-ankle & absent & absent & $2.2-41.4(\mu \mathrm{V})$ \\
\hline
\end{tabular}

Surface temperature right leg $34^{\circ} \mathrm{C}$.

$\mathrm{DML}=$ distal motor latency (ms); $\mathrm{MCV}=$ motor conduction velocity $(\mathrm{ms}) ; \mathbf{M A P}=$ compound muscle action potential (mV); $\mathrm{NAP}=$ mixed nerve action potential $(\mu \mathrm{V}, \mathrm{ms}) ; \mathrm{SAP}=$ sensory action potential $(\mu \mathrm{V}, \mathrm{ms}) ; \mathrm{F}=$ finger.

Ulnar nerve: surface electrode on abductor digiti minimi (ADM) (motor) and wrist (sensory).

Median nerve: surface electrode on abductor pollicis brevis (APB) (motor), and wrist (sensory).

Lateral popliteal nerve: surface electrode on extensor digitorum brevis (EDB) (motor), needle electrode at fibula (mixed nerve action potential).

Table 2 Mixed nerve action potentials nine days after onset of Miller Fisher syndrome (case 1)

\begin{tabular}{|c|c|c|c|c|c|c|c|c|}
\hline \multirow[b]{2}{*}{ Nerve } & \multirow[b]{2}{*}{ Stimulus } & \multirow[b]{2}{*}{ Recorded } & \multicolumn{3}{|c|}{ Amplitude $(\mu V)$} & \multicolumn{3}{|c|}{ Velocity $(\mathrm{m} / \mathrm{s})$} \\
\hline & & & Right & Left & Normal & Right & Left & Normal \\
\hline \multirow[t]{2}{*}{ Median } & wrist & elbow (SE) & 5 & 10 & $>20$ & 64 & 68 & $\begin{array}{l}66.8 \pm 3.9 \\
\text { (to peak) }\end{array}$ \\
\hline & above wrist* & elbow (SE) & 24 & 21 & & 66 & 68 & \\
\hline Ulnar & wrist & elbow (SE) & 7 & ND & $33-117$ & 62 & ND & $\begin{array}{l}48-60 \\
\text { (to peak) }\end{array}$ \\
\hline Lateral popliteal & ankle & $\begin{array}{l}\text { fibula } \\
\text { (needles) }\end{array}$ & absent & ND & $2.0-15.5$ & - & ND & $\begin{array}{l}33.8-51.8 \\
\text { (to peak) }\end{array}$ \\
\hline
\end{tabular}

$\mathrm{SE}=$ surface electrode $\mathrm{ND}=$ not done; $* 4.5 \mathrm{~cm}$ above wrist on the right and $6 \mathrm{~cm}$ on the left. 
sense was slightly impaired in the toes. Two point discrimination was impaired in the fingers (12-35 $\mathrm{mm})$. Vibration sense was normal. General examination was unremarkable.

$\mathrm{He}$ was given a 20 day course of ACTH injections starting with 80 units intramuscularly and gradual reduction. He improved rapidly and when discharged on 24 February 1972 he had only subjective sensory disturbance in the fingertips and toes and absent deep tendon reflexes. When last seen on 18 April 1972 reflexes were still absent.

\section{INVESTIGATIONS}

Lumbar puncture on 18 January 1972 showed an opening pressure of $100 \mathrm{~mm} \mathrm{H} \mathrm{H}_{2} \mathrm{O}$. The CSF contained protein $0.4 \mathrm{~g} / 1$, no cells, Pandy test negative, Lange curve normal. A repeat on 3 February showed protein $1.4 \mathrm{~g} / \mathrm{l}$, no cells, Pandy test positive, Lange curve normal. Haematological biochemical, and virological screening were negative. Cochlear function was normal on 17 April but caloric responses were severely reduced bilaterally with optic fixation and increased without fixation. Optokinetic nystagmus was present, brisk, and symmetrical. It was concluded that the findings would accord with bilateral lesions involving the peripheral vestibular nerves or ganglia and that there was no evidence of cerebellar involvement (Dr M. R. Dix).

Results of nerve conduction studies are summarised in Table 3. It can be seen that motor conduction did not change significantly during the 10 months of follow-up. The values for median and ulnar SAPs after 10 months show that they were pathologically small and probably delayed up to the 40th day of illness. The significance of the variation in size of the lateral popliteal mixed nerve action potential is less certain but the decrement of the extensor digitorum brevis compound muscle action potential (with a surface electrode) evoked by stimulation of the right lateral popliteal nerve 20 days after the onset may be significant.

\section{Discussion}

Both cases presented all the features described in the Miller Fisher syndrome, that is, acute onset of ataxia, ophthalmoplegia, and arreflexia, elevated CSF protein, and a benign course.

Table 3 Serial nerve conduction studies in Miller Fisher syndrome (case 2)

\begin{tabular}{|c|c|c|c|c|c|c|c|}
\hline \multicolumn{2}{|c|}{ Time after onset } & \multirow{2}{*}{$\begin{array}{l}\text { Three days } \\
1.2 \\
67 \\
9.5\end{array}$} & \multirow[t]{2}{*}{13 days } & \multirow[t]{2}{*}{20 days } & \multirow[t]{2}{*}{40 days } & \multirow{2}{*}{$\begin{array}{l}10 \text { months } \\
2.0 \\
59 \\
10\end{array}$} & \multirow{2}{*}{$\begin{array}{l}\text { Normal values } \\
\begin{array}{l}<4.0 \\
47-65 \\
>3\end{array}\end{array}$} \\
\hline $\begin{array}{l}\mathbf{R} \text { ulnar } \\
\text { nerve }\end{array}$ & $\begin{array}{l}\text { DML } \\
\text { MCV (Elbow-wrist) } \\
\text { MAP (Wrist) }\end{array}$ & & & & & & \\
\hline $\begin{array}{l}\mathbf{R} \text { lateral } \\
\text { popliteal } \\
\text { nerve }\end{array}$ & $\begin{array}{l}\text { DML } \\
\text { MCV (Knee-ankle) } \\
\text { MAP (Ankle) } \\
\text { NAP Amplitude } \\
\quad \text { Velocity (to peak) }\end{array}$ & $\begin{array}{l}3.4 \\
48 \\
7.5 \\
4 \\
44\end{array}$ & & $\begin{array}{c}4.5 \\
49 \\
3.5 \\
4 \\
43\end{array}$ & $\begin{array}{r}2 \\
57\end{array}$ & $\begin{array}{r}3 \\
50\end{array}$ & $\begin{array}{l}<7.0 \\
36-64 \\
>3 \\
2-15.5 \\
33.8-51.8\end{array}$ \\
\hline $\begin{array}{l}\mathbf{R} \text { median } \\
\text { SAP } \\
\text { (F2-wrist) } \\
\end{array}$ & $\begin{array}{l}\text { Amplitude } \\
\text { Latency to peak }\end{array}$ & $\begin{array}{l}10 \\
2.8\end{array}$ & $\begin{array}{l}9 \\
2.8\end{array}$ & $\begin{array}{l}8 \\
2.4\end{array}$ & $\begin{array}{l}5 \\
3.3\end{array}$ & $\begin{array}{l}20 \\
2.2\end{array}$ & $\begin{array}{l}9-45 \\
2.5-4.0\end{array}$ \\
\hline $\begin{array}{l}\text { R ulnar } \\
\text { SAP } \\
\text { (F5-wrist) }\end{array}$ & $\begin{array}{l}\text { Amplitude } \\
\text { Latency to peak }\end{array}$ & & & $\begin{array}{l}8 \\
2.4\end{array}$ & $\begin{array}{l}3 \\
3.5\end{array}$ & $\begin{array}{l}11 \\
2.1\end{array}$ & $\begin{array}{l}7-28 \\
2.2-3.4\end{array}$ \\
\hline Others & & $\begin{array}{l}R \text { index } \\
\text { digital } \\
\text { nerve SAP } \\
9 \mu \mathrm{V} \text { (peak } \\
1.3 \mathrm{~ms} \text { ) }\end{array}$ & $\begin{array}{l}\text { R median } \\
\text { (elbow- } \\
\text { wrist) DML } \\
3.2 \mathrm{~ms} \\
\text { MCV } 62 \mathrm{~m} / \mathrm{s} \\
\text { F wave } 28 \\
\text { ms } \\
\text { (stimulus } \\
\text { at wrist) }\end{array}$ & $\begin{array}{l}\text { Absent H } \\
\text { reflex } \\
\text { (left calf) } \\
\text { Orb. oculi } \\
\text { reflexes: } \\
\text { absent early } \\
\text { ipsilateral } \\
\text { responses } \\
\text { right and } \\
\text { left, normal } \\
\text { late ipsi and } \\
\text { contralateral } \\
\text { responses } \\
\text { Latency } 3.5 \text { ms } \\
\text { (stimulus at } \\
\text { tragus) }\end{array}$ & & $\cdot$ & $\begin{array}{l}\text { Median } \\
\text { nerve } \\
\text { DML 2.8-4.8 } \\
\text { ms } \\
\text { MCV 49-65 } \\
\mathrm{m} / \mathrm{s} \\
\text { Orbicularis } \\
\text { oculi } \\
\text { reflexes } \\
\text { (see Kimura } \\
\text { et al., 1969) }\end{array}$ \\
\hline
\end{tabular}

Abbreviations and units as in Table 1. 
In case 1 the diagnosis of neurosyphilis was considered in 1974 and rejected after consultation with Dr Caterall (venereologist of the Middlesex Hospital) on account of (1) absence of pleocytosis and negative serology in CSF, and (2) blood serological tests suggestive of former treponemal infection rather than active syphilis. The Miller Fisher syndrome developed long after he had been treated with penicillin and the overall picture, including spontaneous recovery, is not that seen in neurosyphilis. The occurrence of a Bell's palsy and arreflexia in the upper limbs nearly three years earlier with subsequent reappearance of those reflexes a year later, and the episodes of paraesthesia one year and again a few months before his last illness might suggest that he is suffering from a remitting and relapsing type of peripheral neuropathy (Thomas et al., 1969). The finding of right median and ulnar sensory action potentials within normal limits in 1973 and the CSF protein of $0.78 \mathrm{~g} / 1$ in 1974 contrast with the findings of his current illness. In both cases ataxia was a prominent feature and was incapacitating at a time when position sense was normal or minimally affected as has been stressed before (Fisher, 1956; Elizan et al., 1971).

Electromyography did not show evidence of denervation, but the interference pattern was reduced in most muscles sampled. It has been suggested that evidence of denervation in the Guillain-Barré syndrome may indicate that clinical recovery will not be complete (McLeod et al., 1976; Raman and Taori, 1976). Fibrillation in the facial muscles in three cases of Miller Fisher syndrome was claimed by Van Allen and MacQueen (cases 2, 3, 4) but were not reported in our case 2 . These authors also describe reduced interference pattern with small motor unit potentials in the eye muscles. Elizan et al. (1971) reported normal electromyography in two cases (cases 8 , 11 ), one of them at the 28th day of illness, but no details of the muscles sampled were given. Motor conduction velocities and distal motor latencies were within normal limits in our patients apart from a lateral popliteal nerve motor conduction velocity at the 53rd day of illness which is just below the normal range in case 1. In the Elizan et al. (1971) series "conduction velocity in the legs' was found to be normal in case 8, 'motor conduction' was normal in case 11 , but case 10 had 'prolonged distal latencies'. All these findings are well known to occur also in Guillain-Barré syndrome (Isch-Treussard et al., 1962; Lambert, 1962; Lambert and Mulder, 1964) but slowing of conduction in more proximal segments of the peripheral nerves, as shown by Kimura and Butzer
(1975) using measurements of $F$ wave conduction velocity, cannot be excluded in our patients. In case 1 the decrement observed in the amplitude of the compound action potential across the elbows (33\% on the right and $43 \%$ on the left) suggests superadded lesions in both ulnar nerves. Similarly, the increase in amplitude of both median mixed nerve action potentials with stimulation above the carpal ligament (Table 2) might suggest bilateral lesions at this level. Slowing of conduction at common sites of nerve compression has been noted in the Guillain-Barré syndrome (Lambert and Mulder, 1964), and the reduced right ulnar and absent right lateral politeal mixed nerve action potentials in case 1 (Table 2) as well as the small lateral popliteal mixed nerve action potential in case 2 (Table 3 ) are comparable with their findings for motor conduction.

Whether the absence of $\mathrm{H}$ reflexes is due to lesions on the sensory or motor pathways, or both, is uncertain but the absence of significant limb weakness favours the former. Absence of $\mathrm{H}$ reflexes in the lower limbs was reported previously in one patient with Fisher's syndrome by Elizan et al. (1971) (case 8).

The striking feature of the nerve conduction studies is the abnormality of sensory action potentials. In our case 1 they were absent in upper and lower limbs, with the methods used here, at the ninth day of illness but a small median nerve SAP was recorded 55 days after the onset when the only sign was arreflexia. In case 2 the median nerve SAP was initially interpreted as normal but by the 40th day after onset it was clearly small. The amplitude 10 months after the illness shows retrospectively that all previous values were below normality for that patient, the latency to peak suggesting also that there had been slowing of sensory conduction.

It may be concluded that the electromyography and nerve conduction findings in the two patients do not differ in any way from those known to occur in peripheral neuropathy, including the Guillain-Barré syndrome. In both patients the total or partial recovery of the sensory action potentials, the absence of denervation, and the rapid clinical recovery suggest that the peripheral neuropathy is probably a demyelinating type.

The mechanism of the ataxia in the Miller Fisher syndrome remains obscure. Neuro-otology did not show evidence of brain stem dysfunction in our patients and there is no available evidence of involvement of the cerebellum or cerebellar pathways in this syndrome. No obvious correlation was seen between the SAP amplitude and clinical ataxia. Thus in the first patient the median 
nerve SAP had reappeared at the 55th day when the ataxia had cleared, but in the second case the smallest sensory action potentials were seen at the 40th day after onset when there was no clinical ataxia. There was also no obvious correlation between SAP amplitude and sensory signs, as has been noted before (Gilliatt and Sears, 1958).

This report provides evidence that in spite of the mild sensory signs there may be a profound disturbance of conduction in peripheral sensory fibres in the Miller Fisher syndrome, and that it may require careful serial studies to show it. It gives no direct evidence of involvement of afferent nerve fibres from muscle spindles, a mechanism for the ataxia implied by Miller Fisher (1956) and suggested later by Hopkins (1971) after the observations of McDonald and Gilman (1969).

The two patients were under the care of Professor R. W. Gilliatt. I am grateful to him and to Dr R. G. Willison for helpful criticism. Thanks are also due to $\operatorname{Dr}$ R. M. Sherratt for useful suggestions and to Miss J. Savvides for typing the manuscript. The electromyographic and nerve conduction studies were carried out in the Department of Applied Neurophysiology, National Hospital, Queen Square.

\section{References}

Asbury, A. K., Arnason, B. G., and Adams, R. D. (1969). The inflammatory lesion in idiopathic polyneuritis. Its role in pathogenesis. Medicine (Baltimore), 48, 173-215.

Baruk, H., and Poumeau De Lille, G. (1934). Un cas d'ataxie aigue 'polyneuritique' curable avec disociation albumino cytologique. Revue Neurologique, 2, 830-833.

Bignami, A., and Senin, M. (1963). Acute internal and external ophthalmoplegia with muscle weakness. Lancet, 1, 1110.

Collier, J. (1932). Peripheral neuritis. Edinburgh Medical Journal, 39, 672-688.

Di Benedetto, M. (1970). Sensory nerve conduction in lower extremities. Archives of Physical Medicine and Rehabilitation, 51, 253-258.

Downie, A. W., and Scott, T. R. (1967). An improved technique for radial nerve conduction studies. Journal of Neurology, Neurosurgery, and Psychiatry, 30, 332-336.

Elizan, T. S., Spire, J. P., Andiman, R. M., Baughman, F. A., and Lloyd Smith, D. L. (1971). Syndrome of acute idiopathic ophthalmoplegia with ataxia and areflexia. Neurology (Minneapolis) 21, 281-292.

Fisher, M. (1956). An unusual variant of acute idicpathic polyneuritis (Syndrome of ophthalmcplegia ataxia and areflexia). New England Journal of Medicine, 255, 57-65.

Gilliatt, R. W., and Sears, T. A. (1958). Sensory nerve action potentials in patients with peripheral nerve lesions. Journal of Neurology, Neurosurgery, and Psychiatry, 21, 109-118.

Gilliatt, R. W., and Thomas, P. K. (1960). Changes in nerve conduction with ulnar lesions at the elbow. Journal of Neurology, Neurosurgery, and Psychiatry, 23, 312-320.

Gilliatt, R. W., Goodman, H. V., and Willison, R. G. (1961). The recording of lateral popliteal nerve action potentials in man. Journal of Neurology, Neurosurgery, and Psychiatry, 24, 305-318.

Guillain, G. (1936). Radiculoneuritis with acellular hyperalbuminosis of the CSF. Archives of Neurology and Psychiatry (Chicago), 36, 975-990.

Haymaker, W., and Kernohan, J. W. (1949). The Landry-Guillain-Barré syndrcme. A clinicopathological report of fifty fatal cases and a critique of the literature. Medicine (Baltimore), 28, 59-141.

Hopkins, A. (1971). Symmetrical external ophthalmcplegia in acute infective polyneuritis. Zeitschrift für Neurologie, 199, 140-144.

Isch-Treussard, C., Buchheit, F., and Isch, F. (1962). Evolution de la vitesse de conduction nerveuse dans trois cas de polyradiculonevrite de Guillain-Barré. Electroencephalography and Clinical Neurophysiology, Supplement 22, 51-4.

Kimura, J., Powers, J. M., and Van Allen, M. W. (1969). Reflex response of orbicularis oculi muscle to supraorbital nerve stimulation. Study in normal subjects and in peripheral facial paresis. Archives of Neurology (Chicago), 21, 193-199.

Kimura, J., and Butzer, J. F. (1975). F wave conduction velocity in Guillain-Barré syndrome. Assessment of nerve segment between axilla and spinal cord. Archives of Neurology (Chicago), 32, 524-529.

Lambert, E. H. (1962). Diagncstic value of electrical stimulation of motor nerves. Electroencephalography and Clinical Neurophysiology, Supplement 22, 9-16.

Lambert, E. H., and Mulder, D. W. (1964). Nerve conduction in the Guillain-Barré syndrome. Electroencephalography and Clinical Neurophysiology. 17, 86.

Marinesco, G. (1927). Sur une forme speciale d'ataxie aigue relevant de la lésion inflammatoire des ganglions spinaux et des nerves péripheriques avec participation de la moelle et du bulbe. Revue Neurologique, 2, 337-351.

Martin, J. J. (1960). Polyradiculonévrites aiguës et subaiguës. Acta Neurologica et Psychiatrica Belgica, 60, 1087-1139.

McDonald, W. I.. and Gilman, S. (1968). Demyelination and muscle spindle function. Effect of diphtheritic polyneuritis on nerve conduction and muscle spindle function. Archives of Neurology (Chicago), $18,508-519$.

McLeod, J. G., Walsh, J. G., Prineas, J. W., and Pollard, J. D. (1976). Acute idiopathic polyneuritis. A clinical and electrophysiological follow-up study. Journal of the Neurological Sciences, 27, 145-162.

Munsat, T. L., and Barnes, J. E. (1965). Relation of multiple cranial nerve dysfunction to the Guillain- 
Barré syndrome. Journal of Neurology, Neurosurgery, and Psychiatry, 28, 115-120.

Raman, P. T., and Taori, G. M. (1976). Diagnostic significance of electrodiagnostic studies in the Guillain-Barré syndrcme. Journal of Neurology, Neurosurgery, and Psychiatry, 39, 163-170.

Richter, R. B. (1962). The ataxic form of polyradiculoneuritis (Landry-Guillain-Barré syndrome): clinical and pathologic observations. Journal of Neuropathology and Experimental Neurology, 21, 171-184.

Russell, W. O., and Moore, W. L. (1943). Permanent damage to the nervous system following an attack of polyradiculoneuritis (Guillain-Barré syndrome).
Report of a case, with necropsy. Archives of Neurology and Psychiatry (Chicago), 49, 895-903.

Thomas, P. K., Lascelles, R. G., Hallpike, J. F., and Hewer, R. L. (1969). Recurrent and chronic relapsing Guillain-Barré polyneuritis. Brain, 92, 589-606.

Van Allen, M. W., and Macqueen, J. C. (1964). Ophthalmoplegia ataxia and the syndrome of Landry-Guillain-Barré: a report of four cases with comments on the ophthalmoplegia. Transactions of the American Neurological Association, 89, 98-103.

Van Bogaert, L. (1958). La poly-ganglio radiculonévrite. In Handbuch der Speziellen Pathologischen Anatomie und Histologie. XIII/2, Bandteil A, pp. 298-213. Springer Verlag: Berlin. 